33-34 | 2003

Sortir de la nuit

Jean-Luc Lambert

\title{
Chapitre II. Morts et barus'i dans la mythologie
}

Chapter II. The dead and the barus'i in mythology

Jean-Luc Lambert

\section{(2) OpenEdition}

Journals

Édition électronique

URL : https://journals.openedition.org/emscat/1377

DOI : 10.4000/emscat.1377

ISSN : 2101-0013

Éditeur

Centre d'Etudes Mongoles \& Sibériennes / École Pratique des Hautes Études

Édition imprimée

Date de publication : 2 décembre 2003

Pagination : 343-396

ISSN : 0766-5075

Référence électronique

Jean-Luc Lambert, «Chapitre II. Morts et barus'i dans la mythologie », Études mongoles et sibériennes, centrasiatiques et tibétaines [En ligne], 33-34 | 2003, mis en ligne le 17 mars 2009, consulté le 13 juillet 2021. URL : http://journals.openedition.org/emscat/1377 ; DOI : https://doi.org/10.4000/emscat.1377

Ce document a été généré automatiquement le 13 juillet 2021.

(C) Tous droits réservés 


\title{
Chapitre II. Morts et barus'i dans la mythologie
}

\author{
Chapter II. The dead and the barus'i in mythology
}

Jean-Luc Lambert

\section{RÉSUMÉS}

Des mythes développent la conception des relations entre vivants et morts exposée au chapitre précédent. Ils précisent que les défunts récents peuvent être ranimés mais qu'il est impossible de ramener à la vie un mort ayant intégré la société des défunts. Ils indiquent que le chamane des vivants ne peut en aucun cas prendre une épouse chez les défunts. Ils mettent en évidence que le chamanisme nganassane est sous-tendu par un système d'échange. D'autres mythes associent barus'i et vivants. Ils montrent un barus'i s'échappant par une coupure au doigt. (Selon une version, cette moitié d'homme protectrice devient même la divinité qui défend les Nganassanes contre le «Dieu russe ».) Ceci évoque la particularité des gants chamaniques gauches, qui n'ont que trois doigts, peut-être pour que les chamanes puissent libérer leur souffle vital - comme le font les défunts dont les doigts seraient sectionnés en arrivant dans le monde des morts. Par ailleurs, la divinité nénètse des morts et de la maladie est, elle aussi, parfois représentée sous forme de moitié d'homme. Tout ceci conduit à élaborer une hypothèse sur cette figure syncrétique du panthéon nénètse.

Certain myths develop further the way relations between the living and the dead are conceived of, as shown in the preceding chapter. These myths make clear that the recently deceased may be revived, but that it is impossible to resuscitate a dead man already incorporated into the society of the dead. They indicate that the shaman of the living can never take for wife a dead woman. They show that an exchange system underlies Nganasan shamanism. Other myths associate the barus'i with the living. These have a barus'i fleeing through a finger-cut. (According 
to one version, this half-man even becomes the divinity protecting the Nganasans from the "Russian God".) This recalls a particularity of left-hand shamanic gloves, which have only three fingers, perhaps so that the shamans might release their breath of life-like the recently deceased who are supposed to have their fingers cut off when entering the world of the dead. Moreover the Nenets divinity of the dead and of illness too is sometimes represented as a halfman. All of which leads to a conjecture concerning this syncretic figure of the Nenets pantheon.

\section{INDEX}

nomsmotscles Enets, Nenets, Nganasan, Samoyède

Thèmes : chamanisme, fêtes, littérature, mythologie, nomadisme, organisation sociale, parenté, religion, représentations

Index géographique : Arctique, Russie, Sibérie occidentale, Sibérie septentrionale, Taïmyr, Toundra

Mots-clés : alliance, chamane, mythe, rituel

Keywords : marriage, myth, ritual, shaman

\section{AUTEUR}

JEAN-LUC LAMBERT 